\title{
UPAYA MERINTIS DESA WISATA MELALUI PELATIHAN DAN PENDAMPINGAN MASYARAKAT DI DESA CARANGREJO KECAMATAN SAMPUNG KABUPATEN PONOROGO
}

\author{
Oleh: \\ ${ }^{1)}$ Reni Albertin Putri, ${ }^{2)}$ Nurisa Hardiyanti, ${ }^{3)}$ Kiki Wijayanti \\ ${ }^{1,2)}$ Fakultas Matematika dan IImu Pengetahuan Alam, ${ }^{3)}$ Fakultas IImu Sosial \\ Universitas Negeri Malang \\ 1albertin.reni@gmail.com
}

\begin{abstract}
Abstrak
Desa Carangrejo, Kecamatan Sampung, Kabupaten Ponorogo memiliki potensi wisata berupa persawahan, perkebunan, pegunungan, serta makam leluhur yang dapat dijadikan ikon dalam proses pengembangan desa wisata. Bulurejo sebagai salah satu dukuh di Desa Carangrejo memiliki potensi sebagai central wisata sebab makam leluhur yang menjadi ikon desa berada di dukuh ini. Selain hal tersebut, Dukuh Bulurejo juga memiliki hasil bumi yang dijadikan produk unggulan, seperti pisang, kunyit, dan jahe. Metode yang digunakan oleh mahasiswa KKN UM 2018 untuk mewujudkan Desa Carangrejo menuju desa wisata ialah pelaksanaan pendampingan pengembangan desa. Tahap pengembangan yang dilakukan melalui 2 cara, yaitu: 1) melaksanakan kesiapan fisik, dan 2)melaksanakan pengembangan potensi dengan melakukan pendampingan dan pelatihan pemberdayaan masyarakat, serta kemandirian dalam mengembangkan potensi desa yang dimiliki.Tahap pelaksanaan kesiapan fisik yang dimaksud berupa pemberian nama jalan, pengadaan plang nama jalan, petunjuk arah menuju makam leluhur, serta pembuatan 33 tempat sampah permanen yang diletakkan di titik-titik yang telah disepakati. Tahap pelaksanaan pengembangan potensi desa melalui pelatihan dan pendampingan berupa pengolahan kunyit dan jahe, pembuatan sabun alami, pemanfaatan daun serta pelepah pisang yang banyak ditanam masyarakat namun kurang dimanfaatkan secara maksimal. Pelatihan dan pendampingan yang dilakukan mahasiswa KKN UM ini dilakukan dalam rangka menyiapkan Desa Carangrejo menuju desa wisata.
\end{abstract}

Kata Kunci: desa wisata, pelatihan, pendampingan

\begin{abstract}
Desa Carangrejo, Kecamatan Sampung, Kabupaten Ponorogo has various tourism potential, such as rice fields, plantations, mountains, and ancestral graves that can be used as icon in term of developing its tourism. Bulurejo as one of the hamlets in Desa Carangrejo has its potential as the central of tourism because the ancestral grave of the village's icon is located there. Besides, Dukuh Bulurejo also continuously produces crops which becomes superior, such as banana, turmeric, and ginger. The method used by Internship student of UM 2018 in purpose of making Desa Carangrejo to be tourism village is by implementing village development assistance. The development stage is done in two ways: 1) implementing physical readiness, and 2) implementing potential development by providing training and assistance for community's empowerment, also independence in developing village's potentials. Implementation of physical readiness stage is done in the form of giving street name, procurement of street sign, direction sign leading to ancestral grave, and preparing thirty-tree (33) permanent bins that are located in some agreed points. Implementation of village's potential development stage is done by cultivating turmeric and ginger, producing natural soap, utilization banana leaves and bark that was found and planted in many places but not utilized optimally. Training and assistance programs with the aim of developing village's potency was done in order to prepare the village to be the tourism village.
\end{abstract}

Keywords: tourism village, training, assistance

\section{PENDAHULUAN}

Desa wisata merupakan salah satu bentuk penerapan pembangunan pariwisata berbasis masyarakat dan berkelanjutan. Melalui pengembangan pariwisata ini dilakukan pengenalan dan promosi budaya yang dimiliki suatu desa tanpa merusak budaya tersebut (Dewi dkk, 2013). Oleh karena itu sebuah desa wisata tentunya memerlukan suatu ciri khas sebagai tujuan wisata (Oka A. Yoeti (1996) dalam Zakaria (2014). Damanik (2009) 
mengungkapkan bahwa pengembangan desa wisata hendaknya juga mempertimbangkan potensi-potensi yang dimiliki desa. Sehingga, melalui pengembangan ini diharapkan dapat mendorong sektor ekonomi lain seperti kerajinan, industri kecil rumah tangga, dan lain sebagainya. Selain adanya ciri khas dan potensi desa, salah satu komponen desa wisata adalah adanya aksebilitas dan infrastruktur yang mendukung desa wisata tersebut (Putra dalam Zakaria (2014)). Hal ini selaras dengan pendapat Priyanto dan Dyah (2015) yang menyatakan bahwa salah satu syarat terbentuknya desa wisata adalah adanya aksebiltas yang baik dan objek wisata yang menarik. Berdasarkan kriteria tersebut, Desa Carangrejo, Kecamatan Sampung, Kabupaten Ponorogo merupakan salah satu desa yang memiliki modal dan potensi untuk dikembangkan menjadi sebuah Desa Wisata.

Desa Carangrejo, Kecamatan Sampung, Kabupaten Ponorogo merupakan desa dengan wilayah yang luas dan penduduknya yang banyak. Desa ini memiliki 9 dukuh, 18 $\mathrm{RW}, 68 \mathrm{RT}$, dengan luas wilayah lebih dari 716 hektar, dan berpenduduk sebanyak 8059 jiwa, $2444 \mathrm{KK}$. Wilayah yang begitu luas inilah yang menjadi alasan pemekaran atau pemecahan Desa Carangrejo menjadi Desa Carangrejo dan Desa Ringin Putih. Hal ini diatur dalam Perda No. 9 Tahun 2011 Tentang Pembentukan Desa Ringin Putih Kecamatan Sampung dan Desa Jrakah Kecamatan Sambit, Kabupaten Ponorogo. Pemecahan ini mengakibatkan Desa Carangrejo tinggal memiliki lima dukuh, yakni Dukuh Carangrejo, Bulurejo, Kalangan, Plebon, dan Tamansari, dengan jumlah penduduk 4868 jiwa, 1540 KK. Selain potensi wilayah luas dan penduduk banyak, Desa Carangrejo memiliki potensi wisata berupa persawahan, perkebunan, pegunungan, serta makam leluhur yang dapat dijadikan ikon dalam proses pengembangan desa wisata.

Bulurejo sebagai salah satu dukuh di Desa Carangrejo memiliki potensi sebagai central wisata sebab makam leluhur yang menjadi ikon desa berada di dukuh ini. Kompleks makam leluhur yang terletak di Dukuh Bulurejo merupakan tempat peristirahatan terakhir dari 3 tokoh penting desa. Ketiga tokoh tersebut adalah Sidiq Purmono, Mbah Doblang (Habib Syeh Muh.Samiun), dan Sabar Iman (Syeh Syarifudin). Beliau-beliau berperan penting dalam penyebaran agama Islam di Desa Carangrejo. Oleh sebab itu, kompleks makam ini pantas dijadikan sebagai situs bersejarah yang menjadikan Desa Carangrejo sebagai desa wisata.

Selain hal tersebut, Dukuh Bulurejo juga memiliki hasil bumi yang dijadikan produk unggulan, seperti pisang, kunyit, dan jahe. Hampir semua masyarakat di Desa Carangrejo menanam pohon pisang, kunyit, serta jahe. Berdasarkan keterangan dari Bapak Kamituwodan perangkat desa, masalah yang dihadapi dalam mengolah hasil bumi yang ada menjadi produk unggulan adalah pengetahuan masyarakat dan karangtarunanya yang masih kurang. Masyarakat juga masih kurang kreatif dalam mengolah hasil bumi yang ada. Kurangnya pengetahuan dan kreatifitas masyarakat membuat mereka tidak memanfaatkan potensi desa dengan maksimal. Masyarakat biasanya hanya menjual kunyit dan jahe secara langsung tanpa diolah, sehingga harga jualnya relatif rendah. Bahkan masyarakat juga hanya menjadikan batang dan daun pisang sebagai limbah tanpa memanfaatkannya. Seandainya limbahlimbah tersebut dimanfaatkan dengan baik akan menghasilkan produk dengan nilai jual tinggi. Limbah koran bekas juga melimpah jumlahnya di Desa Carangrejo. Hampir seluruh masyarakat hanya membakar limbah rumah tangga, seperi koran dan botol tanpa mengolahnya.Bertolak dari permasalahan tersebut maka tercetuslah ide untuk mengadakan pelatihan dan pendampingan dalam mengolah kunyit, jahe, pohon pisang, koran bekas, serta botol bekas menjadi barang yang bernilai jual tinggi.Olahan seperti jamu yang berasal dari kunyit dan jahe, minuman serbuk instant, dan sabun mandi merupakan contoh produk dari pendampingan kerja yang akan dilakukan. Barang-barang bekas yang ada, juga bisa disulap menjadi barang kerajinan yang estetik, misalnya pembuatan wadah buah, piring, dan juga mangkok dari koran bekas yang dipilin dan disusun, serta pembuatan kotak tissue dari pelepah pisang. Hal tersebut dilakukan dalam rangka memaksimalkan potensi desa untuk menuju desa wisata.

Berdasarkan situasi yang terjadi, mahasiswa Kuliah Kerja Nyata (KKN) Universitas Negeri Malang Tahun 2018 bermitra dengan masyarakat dan karangtaruna bersepakat untuk melakukan pelatihan dan pendampingan bersama untuk mengolah potensi desa.. Pelatihan dan pendampingan dilakukan dalam sector fisik dan pemberdayaan. Hal ini merupakan upaya 
untuk merintis Desa Carangrejo sebagai desa wisata yang berdaya tarik tinggi.

\section{METODE}

Metode yang digunakan dalam pelaksanaan pendampingan pengembangan Desa Carangrejo sebagai desa wisata yang dilaksanakan oleh kelompok Kuliah Kerja Nyata (KKN) Universitas Negeri Malang 2018 adalah dengan melakukan kesiapan secara fisik dan pengembangan potensi Desa Carangrejo sebagai desa wisata. Kesiapan fisik yang dimaksud adalah pengadaan sarana dan prasarana yang mendukung aksebilitas dan infrastruktur tujuan wisata di Desa Carangrejo, sedangkan pengembangan potensi yang dimaksud yaitu memberdayakan masyarakat dan mengembangangkan potensi desa yang dimiliki.Hal ini selaras dengan pendapat Priyanto dan Dyah (2015 yang menyatakan bahwa salah satu syarat terbentuknya desa wisata adalah adanya aksebiltas yang baik dan objek wisata yang menarik.

Tahap pelaksanaan yang dilakukan adalah adalah sebagai berikut.

1. Melaksanakan kesiapan fisik berupa pemberian nama jalan beserta pengadaan plang jalan di sekitar objek wisata. Tujuan kegiatan ini untuk meningkatakan kualitas aksebilitas jalan menuju objek wisata. Mengingat akses jalan menuju objek tersebut masih belum bernama yang tentunya akan mengganggu kelancaran menuju tujuan wisata yang diunggulkan. Selain pengadaan plang jalan, diadakan pula tempat sampah permanen dari beton sebagai sarana kebersihan desa. Kebersihan desa sangat dibutuhkan untuk menjaga keasrian, keaslian, serta kenyamanan lingkungan desa terkhusus menuju objek wisata.

2. Melaksanakan pengembangan potensi dengan melakukan pendampingan dan pelatihan pemberdayaan masyarakat, serta kemandirian dalam mengembangkan potensi desa yang dimiliki. Pelatihan dan pendampingan dilakukan dengan memanfaatkan barang-barang yang tersedia di Desa Carangrejo yang tujuannya adalah untuk mendukung pariwisata desa. Sesuai pendapat Andriyani, dkk (2017:2), pengembangan pariwisata pedesaaan didorong oleh faktor pengembangan potensi desa baik alam, sosial maupun budaya

\section{HASIL DAN PEMBAHASAN}

Hasil dari beberapa tahapan pelaksanaan pada kegiatan pelatihan dan pendampingan menuju pengembangan desa wisata di Carangrejo adalah sebagai berikut.

1. Melaksanakan kesiapan fisik berupa pemberian nama jalan dan pengadaan plang nama jalan menuju objek wisata. Salah satu komponen desa wisata adalah adanya aksebilitas dan infrastruktur yang mendukung desa wisata tersebut (Putra dalam Zakaria (2014). Pada mulanya akses umum untuk promosi makam leluhur Desa Carangrejo sangat terganggu. Hal ini disebabkan banyak jalan menuju makam leluhur masih belum bernama. Oleh karena itu, kegiatan perdana yang dilakukan adalah dengan melakukan musyawarah pemberian nama jalan sekitar makam. Musyawarah dilakukan bersama perangkat desa dan sesepuh Desa Carangrejo khususnya Dukuh Bulurejo. Musyawarah yang diselenggarakan pada Selasa, $22 \mathrm{Mei}$ menghasilkan enam nama jalan. Nama jalan yang berhasil dirumuskan adalah Jalan R.A Kartini, Jalan Keling, Jalan Kyai Sidik Purnomo, Jalan Syeikh Syarifudin, Jalan Mbah Doblang, dan Jalan Habib Syeikh Moh. Samiun. Nama-nama tersebut merupakan nama tokoh leluhur desa Carangrejo. Selain nama jalan, pada musyawarah pembahasan program kerja dibahas pula terkait nama situs makam leluhur yang terletak di Dukuh Bulurejo Desa Carangrejo tersebut. Langkah selanjutnya adalah dengan pembuatan plang nama-nama jalan yang telah dirumuskan. Plang jalan yang dibuat berbahan dasar besi. Plang tersebut dipesan untuk kemudian dilakukan pengecatan secara mandiri oleh peserta KKN Universitas Negeri Malang. Setelah dilakukan pengecatan, selanjutnya dilakukan pemasangan pada titik-titik yang telah disepakati. Pemasangan plang nama situs makam leluhur Dukuh Bulurejo juga dilakukan agar wisatawan lebih mudah untuk menuju makam. Upaya lain yang dapat dilakukan untuk mendukung lingkungan wisata yang memiliki daya tarik lebih, dilakukan penataan lingkungan berupa pemberian tempat sampah pada beberapa titik penting. Titik penting yang dimaksud adalah mushola, makam, gardu ronda dan beberapa titik ramai. Tempat 
sampah yang dibuat merupakan tempat sampah permanen yang dibuat dari semen. Terdapat sebanyak 33 buah tempat sampah yang berhasil dibuat secara mandiri oleh peserta KKN yang bekerjasama dengan masyarakat sekitar. Tujuan pengadaan tempat sampah adalah untuk mendukung infrastruktur atau sarana prasarana desa. Hal ini dilakukan untuk mendorong kesadaran warga desa dalam menjaga kebersihan desa sebagai salah satu daya tarik yang perlu dikembangkan dalam rangka menciptakan desa wisata. Masyarakat dan mahasiswa KKN Universitas Negeri Malang memiliki visi yang sama, yaitu menjadikan Desa Carangrejo yang memilki situs makam leluhur ini bisa menjadi desa wisata seperti halnya Desa Slahung, Kecamatan Slahung yang memiliki situs Makam Bupati Gading dan mendapat anggaran dari pemerintah kabupaten untuk melakukan pengembangan (Bappeda Kabupaten Ponorogo, 2018)

2. Melaksanakan pengembangan potensi dengan melakukan pendampingan dan pelatihan pemberdayaan masyarakat, serta kemandirian dalam mengembangkan potensi desa yang dimiliki. Desa Carangrejo memiliki banyak potensi yang dapat dikembangkan. Potensi yang dimaksud meliputi, pertanian, perkebunan, pariwisata, dan sosial budaya. Selain melakukan pengadaan fisik, dalam proses pengembangan desa wisata langkah selanjutnya adalah melakukan pelatihan dan pendampingan dalam rangka mengembangkan setiap potensi yang dimiliki terutama pertanian.

Bersama dengan warga sekitar,peserta KKN UM 2018 melakukan beberapa pelatihan dan pendampingan dalam rangka mengembangkan potensi desa. Pelatihan dan pendampingan dilakukan dalam berbagai jenjang. Mulai dari anak-anak, remaja, hingga orangtua. Misalnya saja tentang mengembangkan potensi pertanian desa. Peserta KKN UM melakukan pelatihan dalam memanfaatkan hasil pertanian desa berupa kunyit dan jahe dengan melibatkan remaja dan ibu-ibu PKK.

Kunyit dan jahe merupakan salah satu hasil pertanian yang banyak ditemukan di Desa Carangrejo. Mulanya kunyit dan jahe hanya diperjual belikan secara langsung atau dimanfaatkan sebagai bumbu dapur. Tentunya hal ini masih sangat perlu dimaksimalkan. Oleh karena itu dalam rangka mengembangkan potensi desa, peserta KKN UM 2018 melakukan pelatihan dan pendampingan pengolahan kunyit dan jahe. Bekerjasama dengan Ibu-lbu PKK sekitar Dukuh Bulurejo, dilakukan pengolahan kunyit dan jahe menjadi olahan jamu serbuk siap minum.

Mengadopsi dari Pudiastutiningtyas, dkk (2015:14), peserta KKN melakukan pelatihan dan pendampingan pembuatan jamu serbuk dengan langkah: 1) menyiapkan alat dan bahan berupa kunyit maupun jahe, gula pasir dan air, 2) memarut kunyit atau jahe dan diambil sari hasil parutan tersebut. Sari kunyit atau jahe tersebut kemudian dimasak diatas kompor dan dicampur dengan gula secukupnya, 3) dilakakukan pengadukan hingga sari pati kunyit atau jahe memadat menjadi serbuk. Hasil dari butiran padatan kunyit atau jahe inilah yang dapat dijadikan sebagai jamu instan sehat hasil olahan kunyit dan jahe.

Proses pembuatan dilakukan dan didemonstrasikan di depan ibu-ibu PKK Dukuh Bulurejo. Beberapa diantara ibu-ibu tersebut mempraktikkan sendiri proses pembuatan serbuk jamu siap minum sesuai dengan petunjuk peserta KKN. Peserta KKN juga memberikan resep dan contoh produk yang didemonstrasikan kepada ibu-ibu untuk dikembangkan lebih lanjut

Potensi pertanian juga dapat dikembangkan dalam proses industri rumah tangga. Salah satunya adalah pembuatan sabun alami. Sabun merupakan salah satu industri yang menjanjikan. Industri rumah tangga pembuatan sabun alami menjadi salah satu produk unggulan masyarakat Madiun dan Malaysia. Masyarakat Madiun menggunakan susu sapi sebagai bahan campuran sabun, sedangkan Malaysia menggunakan tanaman aloe vera dan kopi. Oleh karena itu, Desa Carangrejo yang memiliki hasil tani berupa kunyit dapat memaksimalkannyadengan cara memanfaatkan kunyit sebagai campuran dalam membuat sabun alami sebagai salah satu produk unggulan.

Berdasarkan latar belakang inilah, peserta KKN UM 2018 melakukan pelatihan dan pendampingan dalammemanfaatkan kunyit sebagai salah satu bahan dalam pembuatan sabun alami. Kegiatan ini bekerja sama dengan para remaja karang taruna di Desa Carangrejo. Mengadopsi dari Gusfutri, dkk (2013), peserta KKN UM 2018 
menginformasikan dan memberikan pelatihan pembuatan sabun alami sebagai berikut.

1. Menyiapkan alat dan bahan berupa kunyit, minyak, soda api, minyak zaitun, dan air.

2. Melarutkan soda api ke dalam air.Kemudian masukkan larutan soda api tersebut kedalam minyak goreng. Aduk hingga merata.

3. Menamahkan minyak essensial dan sari kunyit kedalamnya. Aduk hingga merata, kemudianmasukkan ke dalam cetakan yang diinginkan.

4. Tunggu hingga kering. Kemudian dapat dikemas semenarik mungkin.

Selain memberikan informasi terkait pembuatan sabun alami, peserta KKN UM juga melakukan pelatihan pembuatan sabun alami yang dihadiri oleh para remaja karang taruna Desa Carangrejo. Tujuan pelatihan ini adalah untuk memberikan pendampingan dalam rangka menciptakan produk unggulan desa sebagai salah satu daya tarik Desa Carangrejo dalam upaya menuju desa wisata.

Selain potensi pertanian terdapat potensi lain yang cukup baik untuk dikembangkan sebagai salah satu oleh-oleh khas dari Desa Carangrejo. Desa Carangrejo memiliki beberapa titik rerumpunan pohon pisang. Daun pohon pisang yang dianggap tidak berguna dan hanya dijadikan sebagai limbah, dapat dimanfaatkan sebagai bahan bernilai jual tinggi. Salah satu caranya adalah dengan melakukan pengolahan pada pelepah pohon pisang sebagai kotak tisu. Oleh karena itu, peserta KKN UM 2018 melakukan pelatihan dan pendampingan pemanfaatan pelepah pisang menjadi kotak tisu yang diikuti oleh anak-anak hingga remaja usia 6-20 tahun. Proses pembuatan yang dilakukan relatif mudah hanya dengan menyiapkan pelepah pohon pisang dan menjemurnya hingga kering. Membuat alas dasar dari kertas buffallo, kemudian menempelkan pelepah pohon pisang kepada dasar yang telah dibuat. Setelah direkatkan maka dilapisi dengan tiner, tunggu hingga kering. Kotak tisu berbahan dasar pelepah pisang telah siap digunakan.

Potensi desa berupa kuantitas anak-anak yang relatif banyak juga dapat dikembangkan sebagai bahan dasar untuk menciptkan masyarakat yang produktif. Salah satu nilai keproduktifan tersebut adalah dengan memanfaatkan barang-barang bekas disekitar, misalnya saja koran bekas. Hampir seluruh masyarakat di Desa Carangrejo membakar sampah-sampah yang dianggap sebagai limbah dan barang tidak berguna. Mengadopsi dari youtube yang di posting oleh akun Mak Soem pada tanggal 2 Februari 2018 salah satu cara memanfaatkan koran bekas adalah dengan memanfaatkannya menjadi kotak tisu, tempat buah dan tempat permen yang menarik dengan cara sebagai berikut. Membuat pilinan-pilinan koran kemudian menyambungkkanya hingga sepanjang yang dibutuhkan. Pilinan tersebut kemudian digulung secara rapat hingga menghasilkan bundaran koran. Bundaran tersebut direkatkan pada bagian ujungnya menggunakan lem kemudian dibentuk sesuai selera.Setelah bentukan mangkuk siap, dilakukan perekatan menggunakan lem kayu untuk mempertahankan bentuk mangkuk. Setelah lem kayu kering,selanjutnya dilakukan pengecatan dengan tiner beberapa kali hingga warna yang diinginkan tercapai.

Pelatihan dan pendampingan yang dilakukan mahasiswa KKN UM 2018 dalam mengembangkan potensi desa dilakukan dalam rangka menyiapkan Desa Carangrejo menuju desa wisata. Pemberdayaan masyarakat untuk mengolah sendiri apa saja yang berada disekitar, akan menjadi nilai lebih untuk Desa Carangrejo. Hal ini akan menambah kekuatan home industri makanan yang dimiliki desa yang meliputi emping jagung, tempe kripik dan rengginan.

\section{SIMPULAN DAN SARAN}

Desa Carangejo memiliki potensi untuk dikembangakan menjadi desa wisata. Potensi desa yang dimaksud berupa kenampakan alamnya, seperti: pegunungan, persawahan, dan perkebunan. Malam leluhur yang membabat desa juga dapat dijadikan ikon desa, serta hasil bumi yang berupa kunyit, pisang, dan jahe juga bisa diolah secara maksimal dan dijadikan ciri khas Desa Carangejo.

Metode yang dilakukan untuk merintis Desa Carangrejo sebagai desa wisata adalah dengan melakukan pendampingan dan pelatihan secara fisik dan pemberdayaan masyarakat dalam rangka memaksimalkan potensi desa.

Pelatihan dan Pendampingan yang dilakukan mahasiswa KKN UM 2018 yang bermitra dengan masyarakat desa dan karang taruna dilakukan dalam beberapa tahapan meliputi perumusan nama jalan dan pembuatan plang jalan menuju objek wisata, pelatihan dan pendampingan pemanfaatan kunyit dan jahe untuk produk jamu serbuk 
dan sabun alami, serta pembuatan kerajinan unik kreatif bernilai guna tinggi dari koran dan pelepah pisang.

\section{DAFTAR PUSTAKA}

Bappeda Kabupaten Ponorogo. 2018, (Online),(https://bappeda.ponorogo.go. id/index.php/data-info/dokumenperencanaan/item/246-daftar-namadesa-wisata). Diakses tanggal 9 September 2019

Damanik, J. 2006. Strategi Promosi Menghadapi Krisis Pariwisata dan Pergeseran Psikografi Wisatawan. Jurnal Pariwisata, 8 (1).

Dewi, M.H.U.D, Fandeli.C, Baiquni, M., 2013. Pengembangan Desa Wisata Berbasis Partisipasi Masyarakat Lokal di Desa Wisata Jatiluwih Tabanan Bali. Jurnal Kawistara. 3(02),117-226.

Mak Soem. 2018. Inspirasi Kerajinan Tangan Mudah dari Koran Bekas. (Online), (https://youtu.be/r6Tg1ulSWo). Diakses tanggal 9 September 2019

Perda No.9 Tahun 2011. Pembentukan Desa Ringin Putih Kecamatan Sampung dan Desa Jrakah Kecamatan Sambit, Kabupaten. Ponorogo: Pemerintah Kabupaten Ponorogo.

Priyanto dan Dyah. 2015. Pengembangan Potensi Desa Wisata Berbasis Budaya Tinjauan terhadap Desa Wisata di Jawa Tengah. Jurnal Vokasi Indonesia.4(1),76-84

Pudiastutingtyas, dkk. 2015. Diverifikasi (Curcuma Domestica) dan kencur (Kaempferia Galanga L) sebagai minuman herbal serbuk siap saji. Metana. 11(01), 13-20.

Zakaria. 2014. Konsep Pengembangan Kawasan Desa Wisata di Desa Badungan, Kecamatan Pakong Kabupaten Pamekasan. Jurnal Teknik Pomits. 3 (2), 245-249. 